Seen from the outside, the twenty-two years between 1951 and 1973 were years of ascent and success. It is best to stop short of exploring the landscape in which he was lost in the end.

\author{
IHOR ŠEVČENKO \\ Harvard University
}

\title{
ARTHUR PRUDDEN COLEMAN, 1897-1974
}

Arthur P. Coleman's academic career was predominantly as a faculty member of the Department of Slavic Languages at Columbia University (1928-48), and as president of Alliance College (1950-62). He was the first American of non-Slavic parentage to obtain a doctor's degree in Slavic at an American university (Columbia. 1925). His most memorable publications are perhaps Essentials of Polish (Glasgow, 1944), in collaboration with Maria Patkaniowska, and his pioneering Report on the Status of Russian and Other Slavic and East European Languages in the United States (New York, 1948). He was a member of the Executive Committee of the National Federation of Modern Foreign Language Teachers Associations, 1950-59, and president, 1953-55. But he was proudest of his organizational role as founder. and the first secretary-treasurer $(1941-49)$ and then president (1950) of the AATSEEL. the first professional association in the Slavic field in America. Those who knew him will remember both his friendly, easygoing good nature and the fervor with which he always sought to foster Polish studies in the United States. especially among those of Polish ancestry.

\section{J. Thomas Shaw \\ University of Wisconsin, Madison}

\section{DONALD A. LOWRIEE, 1889-1974}

On October 12,1974, after a protracted siege of ill health, Donald A. Lowrie died in Meadow Lakes, New Jersey.

Born in 1889 in Seville, Ohio, Lowrie graduated from Wooster College and earned the Ph.D. at Charles University, Prague. He received degrees of doctor honoris causa from Wooster College and from the Russian Orthodox Theological Institute, Paris. He was with the YMCA Russian Service in 1916-19 (Tomsk, Moscow, Northern Russia) and with the emigration in 1919-33 (Berlin. Riga, Prague, Belgrade). Thereafter he was at the University of Paris. then Geneva during the war, and from 1946 to 1955 he was director of the YMCA Press in Paris. Among his publications are The Light of Russia: biographies of Tomáš Masaryk: Saint Sergius, and Nikolai A. Berdiaev (Rebellious Prophet) : and translations of Tsankoff and five of Berdiaev's works. He is survived by his wife. Helen Ogden Lowrie.

In the first decades of this century John R. Mott, that great YMCA leader. chose a corps of able young men and sent them out one by-one into the various countries of the world. Their commission was simple: to master the ways of the country and devote their lives to its people. While they were with us we were enriched. and with their passing we are the poorer. Lowrie was one of these men.

William C. FletcheR
University of Kansas 